\title{
Detoxification of inorganic contaminants in transgenic Arabidopsis thaliana
}

\author{
Raghad Mohammed ${ }^{1}$, Kadhim Ibrahim ${ }^{2}$, Norrya Ali $^{3}$ and Antonious Al-Daoude ${ }^{4}$ \\ ${ }^{1}$ Ministry Science and Technology, Baghdad-Iraq. \\ ${ }^{2}$ Nahrain University, Baghdad-Iraq. \\ ${ }^{3}$ Baghdad University, Baghdad-Iraq. \\ ${ }^{4}$ Atomic Energy Commission, Damascus-Syria. \\ E-mail: raghad1974@yahoo.com
}

\begin{abstract}
In detoxification, the plant takes up the contaminant of concern from soil, water, or a mixture of both, converts it to a volatile form, and releases it to the atmosphere, usually through the leaf stomata. This technique is only suitable for contaminants that do not pose a significant air pollution hazard. Contaminants taken up by the roots pass through the roots to the leaves and are volatized through stomata where gas exchange occurs. This experimental work examines the ability of transgenic Arabidopsis thaliana with P4502E1 gene from rabbit to detoxify for many soil contaminants. The P450 2E1 enzyme controls the rate-limiting step in the metabolism of multiple environmental pollutants. The percentage of transformation increased at the less diluted cultures of Agrobacterium tumefaciens. The ability of transgenic plants were tested for their potential in remediation of metals such as Sodium $(\mathrm{Na})$, Magnesium $(\mathrm{Mg})$, Potassium $(\mathrm{K})$, Calcium $(\mathrm{Ca})$, Manganese $(\mathrm{Mn})$, Iron $(\mathrm{Fe})$, Copper $(\mathrm{Cu})$, Zinc $(\mathrm{Zn})$, and Nickel $(\mathrm{Ni})$. In the present work, transgenic plants were more efficient achieving 31, 46, 42, 48, 33, 51, 35, 29 and 39\% contribution of each to the total value of detoxification contaminants. [DOI: 10.22401/JNUS.20.1.014]
\end{abstract}

Keywords: heavy metals, transformation, Agrobacterium tumefaciens

\section{Introduction}

Geological and anthropogenic activities are two sources of heavy metal contamination [1]. Volcanic activities, industrial effluents, fuel production, mining, smelting processes, military operations, utilization of agricultural chemicals, and manufacturing products release enormous amount of heavy metals into the soil, water and air. Severe contamination of heavy metals in soils may cause a variety of environmental problems, including groundwater contamination and toxicity to plants, animals, and humans [2].

Toxic metals interfer with biochemical and homeostatic processes in the cell through the production of free radicals. The biological consequence of each metal depends on the target accumulation organ, the particular chemical pathway that disrupts the chemical form of the metal, and its oxidation state [3]. Kidney dysfunction is a common effect of exposure to Arsenic (As), Cadmium (Cd), Lead $(\mathrm{Pb})$, Mercury $(\mathrm{Hg})$ and Uranium (U) [4; 5] while chromosomal damage and cancer have been shown in humans exposed to $\mathrm{Cd}$ and $\mathrm{Pb}$ [6]. Neurological, hematological, immune effects have also been shown in humans exposed to lead [7].

The potential of $A$. thaliana as a model organism for genetics was first recognized in 1943 by F. Laibach [8]. Although A. thaliana has no major agronomic significance, it offers several advantages for researchers in many areas of plant biology especially in molecular genetics $[9 ; 10 ; 11]$. Recognized as a tool for the discovery of genes in the role of transformation and phytoremediation, $A$. thaliana has been used for phytotrans formation studies. One such study examined the TNT metabolic pathways within Tobacco [12]. Heavy metal uptake using A. thaliana genes has been more extensively studied such as for arsenic [13] and the elements Zinc (Zn), Cobalt $(\mathrm{Co})$, Copper $(\mathrm{Cu})$, Lead $(\mathrm{Pb})$ and Manganese (Mn) [14]. The use of this model plant in molecular studies has several advantages. By expressing organomercurial lyase (merB) within the same plant, the full pathway from methyl mercury to the least toxic metallic mercury was accomplished. Arabidopsis plants transformed with this gene were tolerant to concentrations of methyl mercury 50 times higher than the 
concentrations to which wild-type plants were tolerant and 10 times higher than those to which plants transformed with merB alone were tolerant [15]. Other strategies are to overexpress ATP sulfurylase [16], glutathione synthetase [17], or $\gamma$-ECS [18] in Indian mustard (Brassica juncea). In a reported field trial on transgenic plants for enhanced remediation, three transgenic lines showed increased accumulation of selenium in leaves. Transgenic Indian mustard plants overexpressing the adenosine triphosphate sulfurylase $(A P S)$ gene accumulated 4.3-fold more selenium in the leaves than the wild-type plants. Transgenics overexpressing the $\gamma$-ECS gene or the $G S$ gene accumulated 2.8- fold and 2.3-fold more selenium in their leaves than wild type respectively. The plants accumulated cadmium, lead, copper, zinc, nickel, and boron [19]. Due to the importance of enhancing transgenic plants for phytoremediation purposes, the aim of this study was to exploit A. thaliana that have been transformation [10] by the gene cytochrome P450 $2 E 1$ from rabbit to enhance their phytovolatization capabilities for detoxification of heavy metal pollutants in soil.

\section{Materials and Methods \\ Plasmid Constructions}

A 1.7-kb EcoRI fragment containing the P450 2E1 cDNA [20] kindly provided by Frank Gonzales (National Institutes of Health, Bethesda, MD) was subcloned between the Mac promote [21] and the mas terminator [22] in the vector pKH200, which was kindly provided by Luca Comai (University of Washington). The 3.8-kb BglII fragment containing Mac-CYP2E1-mas 39 was subcloned into the Bam HI site of the binary vector pCGN1578, which was provided by Luca Comai. The resulting plasmid, pSLD506, was introduced into $A$. tumefaciens by electroporation [23].

\section{Bacterial strains}

Agrobacterium tumefaciens strain C58C1 was used to transform A. thaliana plants. Strains were maintained on LB medium supplementated with the appropriate antibiotics, kanamycin sulfate $(50 \mathrm{mg} / \mathrm{l})$ and carbinicilline $(100 \mathrm{mg} / \mathrm{l})$ at $28^{\circ} \mathrm{C}$.

\section{Agrobacterium infection and co-cultivation}

The proximal end of the cotyledon was gently pricked for ten times to make wounds using sterile needle (Dispovan India Ltd., 0.63 X $25 \mathrm{~mm}$ ). Then the cotyledon explants were immersed in the bacterial culture for $10 \mathrm{~min}$. After that the explants were removed, blotted dry using sterile Whatman no.1 filter paper and inoculated (one explants/culture tube) on MS medium containing IAA $(1.0 \mathrm{mg} / \mathrm{l})$ and $\mathrm{Kn}$ $(1.5 \mathrm{mg} / \mathrm{l})$. The co-cultivation was performed for $0,1,2,3,4$ and 5 days under a $16 \mathrm{~h}$ photoperiod with a light intensity of $30 \mu \mathrm{mol}$ $\mathrm{m}^{2} \mathrm{~s}^{1}$ and kept at $25 \pm 2{ }^{\circ} \mathrm{C}$.

\section{Arabidopsis transformation procedure}

Fifteen-day-old seedlings were transplanted in plastic disposable pots $(10 \times 10 \times 10 \mathrm{~cm})$ at a density of $\sim 8-12$ plants per pot and grown at $23^{\circ} \mathrm{C}$ in a controlled growth chamber under short days (10h photoperiod) to ensure rosette formation. Light was supplied by an equal mixture of Osram White L100/23 and Warm White L100/30 (2400mm) fluorescent tubes with a rating of 8600 lumen. After four weeks plants were removed to a glass house $(16 \mathrm{~h}$ photoperiods) to induce flowering. Primary bolts were clipped to encourage secondary inflorescence growth and plants were used for infiltration 7-10 days later when approximately $30 \%$ of the flower buds were open. A. tumefaciens strain $\mathrm{C} 58 \mathrm{C} 1(\mathrm{p})$ bearing the binary vector was grown in $500 \mathrm{ml} \mathrm{LB}$ supplemented with the appropriate antibiotics at $28^{\circ} \mathrm{C}$ for $48 \mathrm{~h}$ in an orbital shaker $(200$ 250rpm). Cells were harvested by centrifugation at $4000 \mathrm{~g}$ for $10 \mathrm{~min}$ and pelleted cells were resuspended in 5\% sucrose solution supplemented with Silwet-L77 (0.02\%). Each plant pot was inverted into the A. tumefaciens suspension in a plastic container that was big enough to allow the pot to be gently moved in half-circles for 30 seconds. Excess medium was blotted from the dipped plants, which were then covered in a contained propagator for a few days and left to set seeds.

\section{DNA isolation and amplification of bar and CYP 2E1 gene}

Isolation of Genomic DNA: Genomic DNA was isolated from young leaves of control and transformed plants using the method described 
by Al-Daoude [8]. PCR confirmation: For PCR analysis, DNA samples from putative transformants were amplified by bar specific primers. The bar gene fragment $(0.46 \mathrm{~kb})$ was amplified by using the forward primer - 5'ATC GTC AAC TAC ATC GAG AC - $3^{\prime}$ and reverse primer 5'-CCA GCT GCC AGA AAC CCA CGT C-3'. All PCR reactions were performed using a Peltier effect thermal cycler (MJ Research Co., USA). Samples containing $50 \mathrm{ng}$ genomic DNA were first heated at $94^{\circ} \mathrm{C}$ for $5 \mathrm{~min}$ followed by 30 cycles at $94^{\circ} \mathrm{C}$ for $30 \mathrm{~s}, 55 \mathrm{C}$ and $72^{\circ} \mathrm{C}$ for $30 \mathrm{~s}$ followed by $7 \mathrm{~min}$ final extension at $72^{\circ} \mathrm{C}$. Fifty ng of plasmid DNA was used as positive control. The PCR reactions contained $10 \mathrm{p} M$ of each primer, 10 $\mathrm{m} M$ dNTPs mix, $15 \mathrm{~m} M \mathrm{MgCl} 2,50 \mathrm{mM} \mathrm{KCl}$, $10 \mathrm{~m} M$ Tris $\mathrm{HCl}(\mathrm{pH} 9.0), 0.1 \%$ (v/v) Triton $\mathrm{X}-100,2 \mathrm{U}$ of Taq DNA polymerase and 50 ng of template DNA in $1 \mathrm{X}$ reaction buffer. The amplified DNA was analysed using $1.5 \%$ agarose gel electrophoresis. Transformed tissues that were able to regenerate and grow in medium supplemented with kanamycin and carbinicilline were used for genomic extraction and amplification by PCR with specific CYP 2E1 primers (THE 35S promoter with the sequence $5^{\prime}$ CATCGGGAATCTTCTCCAGTTGG 3', and the reverse with the sequence 5 TGAAGGGTGTGCAGCCGACAA 3') using the standard protocols (Sambrook and Russell 2001) to determine the presence of the transgene in the plant genome. PCR was performed using a Mastercycler Gradient (BioRad, USA) machine. All the amplifications were carried out in $25 \mu \mathrm{l}$ reaction volume containing template DNA (300 ng genomic DNA or $50 \mathrm{ng}$ plasmid DNA), 1 X PCR buffer, dNTP mix, $1 \mathrm{mM}$ $\mathrm{MgCl}_{2}, 20$ pmole primer each, and $1.5 \mathrm{U}$ taq DNA polymerase.

\section{Transgenic experiments in the presence of metals}

Samples of contaminated soil were collected from industrial contaminated sites. $A$. thaliana transgenic plants were cultured separately in pots containing soil: peat (1:1, $\mathrm{V}: \mathrm{V})$ with heavy metal concentrations with three replicates. Wild type plants of each plant species were treated with the same treatment as the transgenic ones. All treatments were placed under greenhouse conditions at $25^{\circ} \mathrm{C}$ for 16/8 hrs. light/ dark photoperiod using day light inflorescents at a light intensity of 3000 lux for 12 days. One gram of tissues from each replicate was dried in an oven for $24 \mathrm{~h}$ at $105^{\circ} \mathrm{C}$ (weighed and re-weighed until a constant weight was reached). The samples were then allowed to cool at room temperature before the final weight was taken. The contents of the mineral elements for $\mathrm{K}, \mathrm{Ca}$, $\mathrm{Na}, \mathrm{Mg}, \mathrm{Mn}, \mathrm{Zn}, \mathrm{Cu}, \mathrm{Ni}$ and $\mathrm{Fe}$ were determined using the standard method (aqua regain digestion method) and analyzed by Atomic absorption spectroscopy (AAS), as described by Page et al.[24]. Data analysis by Excel programmer and piecemeal circular three-dimensional displays pie charts fragmented contribution of each to the total value of the total while emphasizing individual values.

\section{Results and Discussion}

Floral dipping method was used to transform A. thaliana with no need for plant tissue culture or regeneration techniques Fig.(1). The technique required culture mediim, hormones, $\mathrm{pH}$ adjustment and $A$. tumefaciens mediated transformation which are applicable at a range of cell densities. Plants of $A$. thaliana were infected with the same A. tumefaciens strain using the floral dip method. Plants were dipped in a solution of $A$. tumefaciens, 5\% sucrose and $0.02 \%$ of the surfactant, Silwet L-77. Plants were inoculated when numerous immature floral buds and few siliques were present. Plants were left to set up seeds and transgenic seeds were selected on Kanamycin containing medium.

Floral dip method is simple and can be conducted by submerging the above-ground parts of the plant into an A. tumefaciens solution for a few seconds. In nature, wounded sites secrete compounds (hexoses at low $\mathrm{pH}$ ) that induce vir genes. In tissue culture transformation methods, the phenolic compound acetosyringone is sometimes added to induce expression of relevant vir genes. Bechtold et al. [25] and Al-Daoude [8] reported that $A$. tumefaciens $\mathrm{C} 58 \mathrm{Cl}$ and pTiC56 genotypes are effective in A. thaliana transformation. Steven et al. [26] reported that 
an increase in Silwet L-77 from $0.005 \%$ to $0.1 \%$ gave higher transformation rate, but high level surfactant (Silwet L-77) can cause plant tissue necrosis under various conditions.

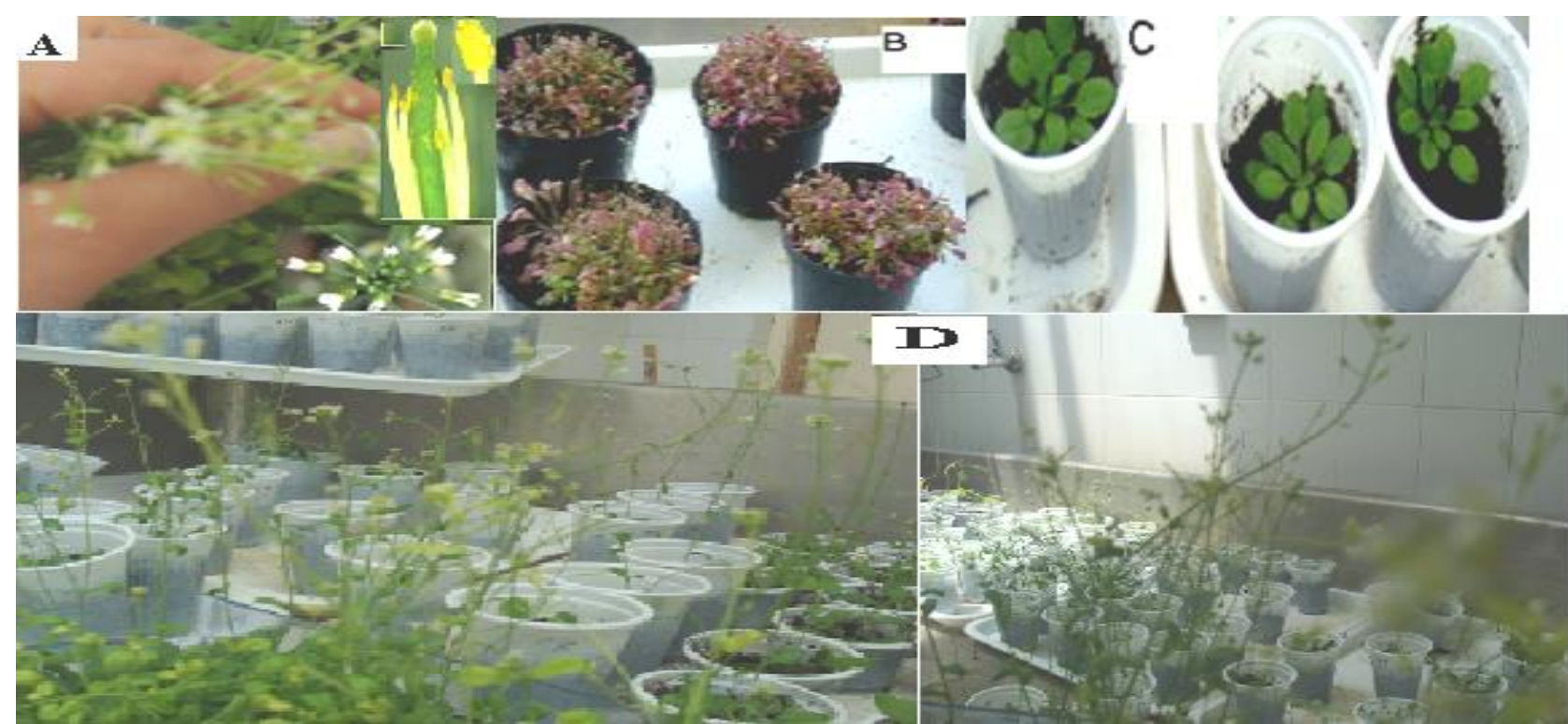

Fig.(1): A. thaliana growth stages using floral dipping method:

A. Primary bolts clipped, secondary bolts about $2-10 \mathrm{~cm}$ (few open flowers)

B. A. thaliana clusters were harvested after floral dipping with A. tumefaciens.

C. A. thaliana germinated on soil containing $50 \mathrm{mg} / \mathrm{l}$ Kanamycin.

D. A. thaliana F1 progeny was harvested and seeds were germinated under Kanamycin selection.

The CYP2E1-P1 and CYP2E1-P2 primers amplified a 410 bp band from both $C Y P 2 E 1$ transgenic plants and pSLD50-6 plasmids, while no PCR products were detected using these two primers for plants and pKH200 plasmids.

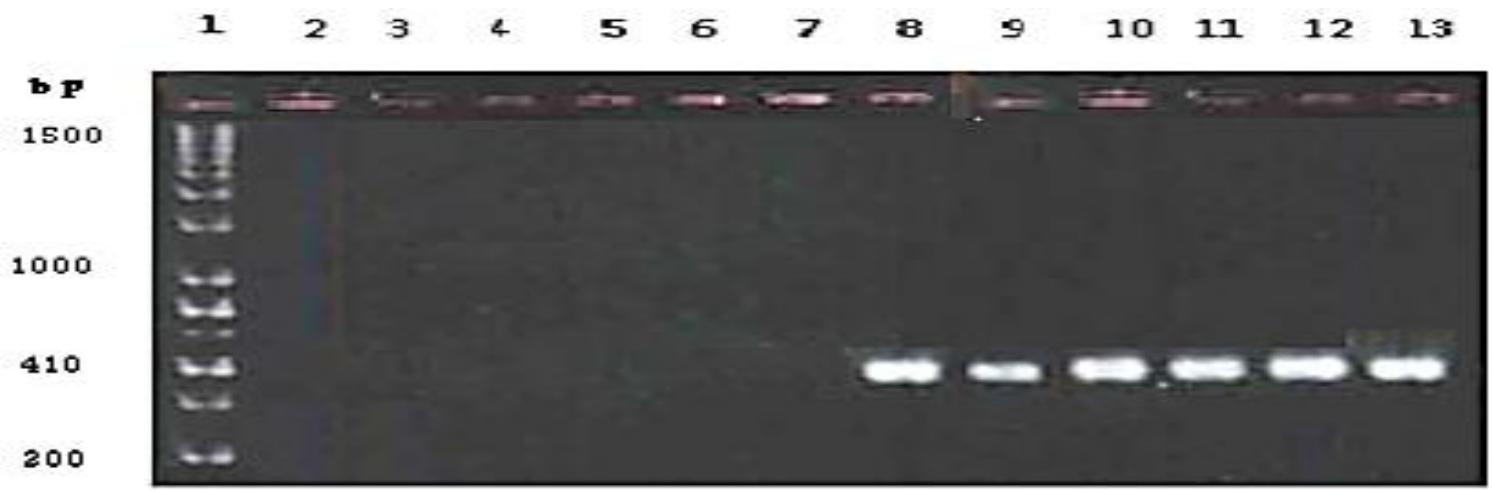

Fig.(2): Agarose (2\%) gel electrophoresis of PCR amplicons using CYP2E1 specific primer (70 v, 60 minutes). Lane 1: DNA Ladder. DNA samples were extracted and tested for the presence of CYP2E1 gene (a band of $\sim 410$ bp was seen). Control plants (2-7 wells) are transgenic plantlets (8-13 wells).

A. thaliana transgenic plants grown on soil containing heavy metals were healthy 12 days after the start of experiment and gained higher fresh reached $61 \%$ and dry weight reached
$63 \%$ than wild type plants which recorded 37 , 39\% respectively Fig.(3). 


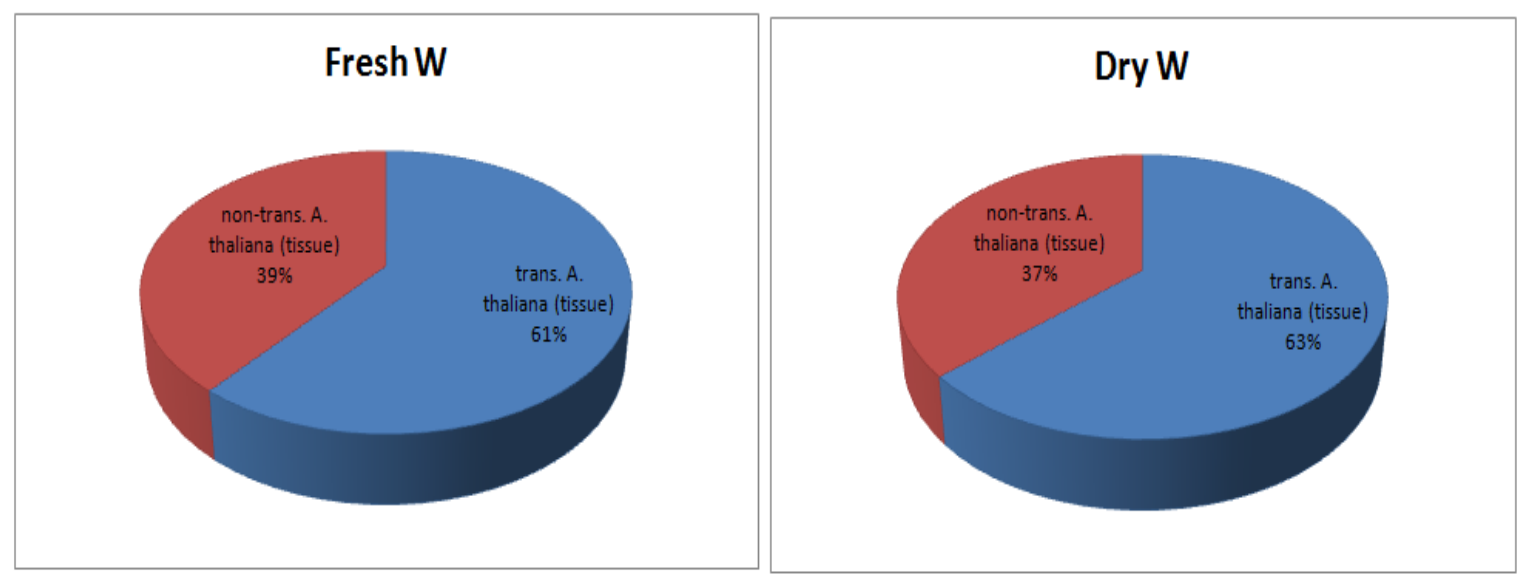

Fig.(3): Fresh and dry weights in transgenic and wild type plants of Arabidopsis thaliana.

\section{Macronutrients}

Arabidopsis transgenic lines showed increased accumulation of $\mathrm{Na}$ reached $31 \%$ compared with wild type plants reached $29 \%$. However, decreases of $\mathrm{Na}$ concentration were $20 \%$ in all soils planted with Arabidopsis transgenic plant and wild type plant respectively Fig.(4). Results showed that increased accumulation up to $42 \%$ compared with wild type plants Fig.(4). While decreases in $\mathrm{Ca}$ concentration were $12 \%$ in soil planted with Arabidopsis transgenic plants compared with $5 \%$ in the same soils cultured in wild type plant. In contrast, an increase $(46 \%)$ of $\mathrm{Mg}$ concentration in transgenic plants in soils planted with transgenic plant compared with wild type plants $(41 \%)$. While the decrease in $\mathrm{Mg}$ concentration reached 12 and $1 \%$ in the same soil planted with transgenic and wild type plants respectivly. Results showed increased accumulation of $\mathrm{K}$ in the transgenic Arabidopsis lines respectively $48 \%$ compared with wild type plants (15\%). Decreases in K concentrations were $14 \%$ and $23 \%$ in soil planted with Arabidopsis transgenic plants and wild type plants respectively. The increase in macro elements accumulation could be explained that $\mathrm{Ca}, \mathrm{K}, \mathrm{Na}$, and $\mathrm{Mg}$ are essential plant nutrients for plant growth and acquired from the soil solution by the root system and translocated to the shoots via the xylem. Roots must balance the delivery of calcium to the xylem with the need for individual root cells to use $\left(\mathrm{M}^{+2}\right)$ cytoplasmic for intracellar signaling. The current hypothesis assumes, that $\mathrm{Ca}^{+2}$ travels apoplastically across the root to the Casparian band which it then circumvents via the cytoplasm of the endodermal cell, although
$\mathrm{Ca}^{+2}$ channels and $\mathrm{Ca}^{+2}-$ ATPases are present and could catalyse $\mathrm{Ca}^{+2}$ influx and enfflux across the plasma membrane of endodermal cells, their transport, or interactions, between $\mathrm{Ca}^{+2}, \mathrm{Br}^{+2}, \mathrm{Sr}^{+2}$ or any cation for transport to the shoot $[27 ; 28 ; 29 ; 30 ; 31]$. 


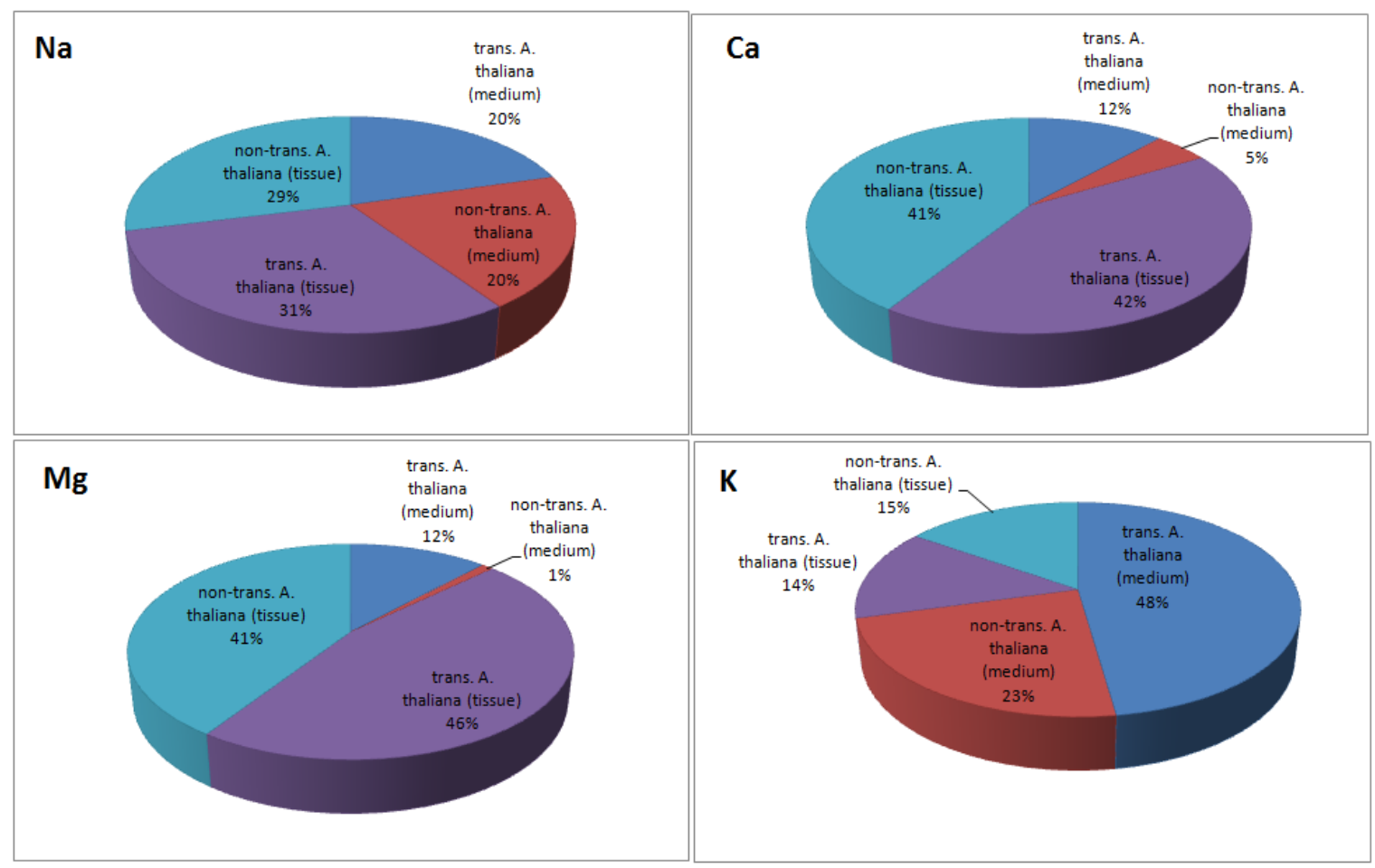

Fig.(4): Macronutrient concentration of Sodium, Calcium, Magnesium and Potassium in Arabidopsis transgenic lines planted on contaminant soils.

\section{Heavy metals}

Arabidopsis transgenic lines showed increased Cooper accumulations up to $35 \%$ compared with wild type plants (55\%). On the other hand, decreases in $\mathrm{Cu}$ concentration was $7 \%$ and $3 \%$ in soil planted with transgenic Arabidopsis and wild type plants respectively Fig.(5). Results showed increased accumulation in $\mathrm{Mn}$ in transgenic plant (33\%) compared with wild type plants (34\%). Fig.(5) shows a decrease (22\%) in Mn concentration in all soils contaminated with heavy metals and planted with transgenic Arabidopsis compared with wild type plants reached $11 \%$.

Results show increased accumulation in $\mathrm{Fe}$ in transgenic Arabidopsis (51\%) compared with wild type plants (41\%) (Figure5). In contrast, a decrease (6 and $2 \%$ ) of $\mathrm{Fe}$ concentration in soils contaminated with heavy metals and planted with transgenic and wild type plants. Results also showed increased accumulations in $\mathrm{Zn}$ in transgenic Arabidopsis lines with increased accumulation percentage reached $29 \%$ compared with wild type plants which reached 27\% Fig.(5). However, decreases in $\mathrm{Fe}$ concentrations were $33 \%$ and $11 \%$ in soil planted with Arabidopsis transgenic and wild type respectively. Arabidopsis transgenic lines showed agian increased accumulation up to $39 \%$ of $\mathrm{Ni}$ compared with wild type plants (25\%) Fig.(5). A reduction in $\mathrm{Ni}$ concentration $(18 \%)$ in all soils planted with transgenic Arabidopsis and wild type.

Toxic effects of metals were assessed inhibition of the primary root length increment as compared to the roots grown by in water. Metal localization in the root apex tissues, the metals were found in both the meristem and in the root cap. Also previous studies have shown that cytochrome P450 2E1 (CYP2E1)dependent transcriptional up-regulation of glutamate-cysteine ligase (GCL). To identify sequences mediating constitutive and induced expression of the catalytic subunit of GCL (GCLC) [32; 33; 31;34]. 


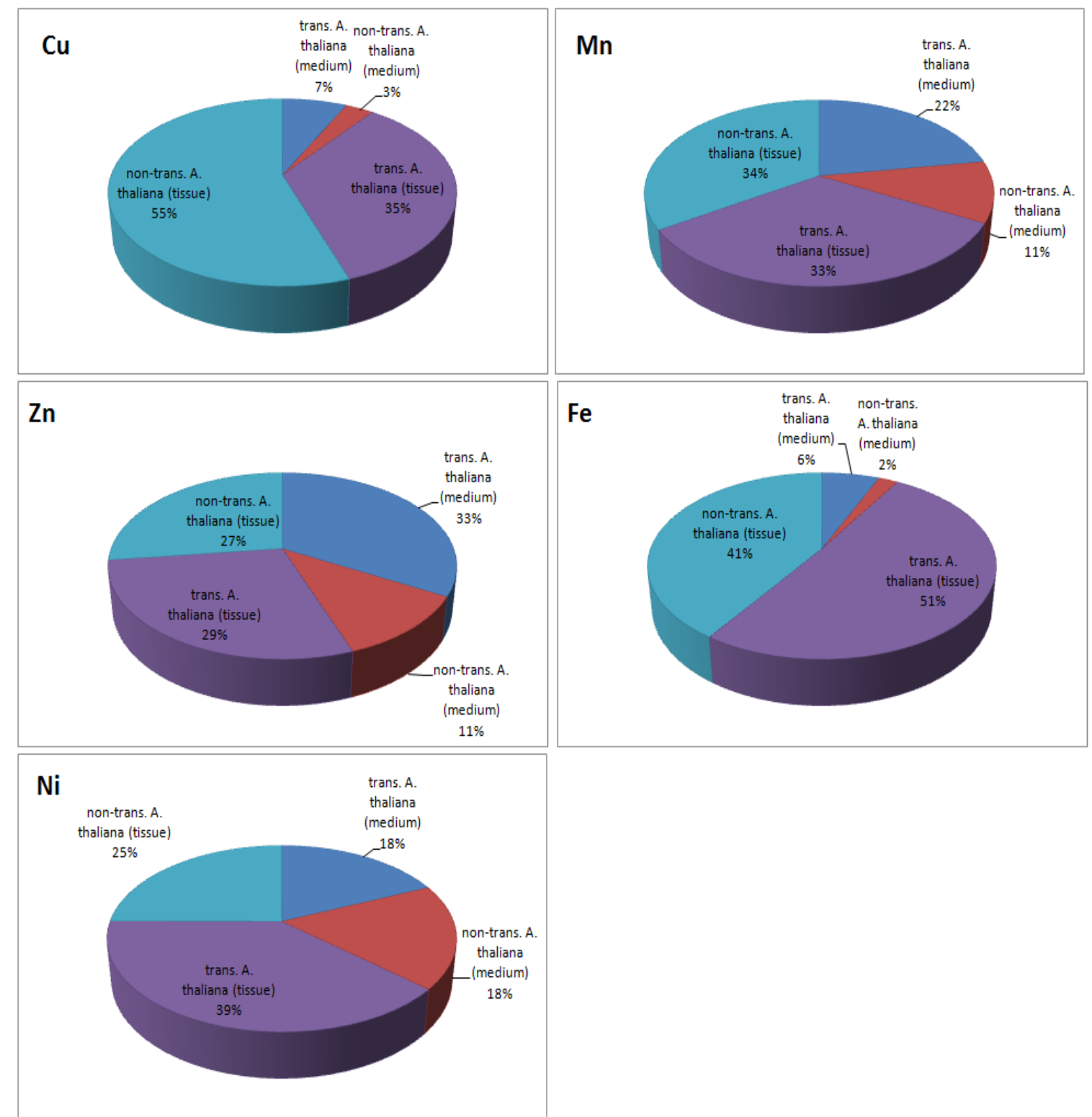

Fig.(5): Micronutrient concentration of Copper, Magnesia, Zinc, Iron and Nikel in Arabidopsis transgenic lines planted on contaminant soils.

\section{References}

[1] Dembitsky, V. Rhizosphere competitiveness of trichloroethylene degrading oplar-colonizing recombinant bacteria. Applied and Environ. Microb., 66: 4673-4678, 2003.

[2] Jianwei, H.; Jianjun, W.; Berti, and Cunningham, U. Phytoremediation of leadcontaminated soils: role of synthetic chelates in lead phytoextraction. Environ. Sci. Techno., 31: 800-805, 1997.

[3] McIntyre, H. C. The effect of photoperiod and temperature on growth and frost resistance of winter rye root systems. Plant Physiol., 79: 519-525, 2003.

[4] Schnoor, J. L.; Licht, L. A.; McCutcheon, S.; Wolfe, N. L. and Carreira, L. H.
Phytoremediation of contaminated soils and sediments Environ. Sci. and Techn., 29: 318-323, 1995.

[5] Stancheva, I. M.; Geneva, Y Y.; Yu M. Accumulation of $\mathrm{Cd}, \mathrm{Pb}$ and $\mathrm{Zn}$ in Tribulus terrestris L. grown on industrially polluted soil and plant antioxidant response. Advances in Environmental Biology, 5: 300-306, 2011.

[6] Tsao, D. T. Overview of phytotechnologies. Advances in Biochemical Engineering and Biotech., 78: 1-50, 2003.

[7] Cunningham, S. D.; Anderson, T. A.; Schwab, A.P. and Hsu, F. C. Phytoremediation of soils contaminated with organic pollutants. Advances in Agronomy., 56: 55-114, 1995. 
[8] Al-Daoude, A. RIN13 is a positive regulator of the plant disease. M.Sc. thesis, Univ. of Imperial, London, UK, 2003.

[9] Wilson, Z. A. Arabidopsis A practical Approach. Oxford University Press, Inc., 22: 47-52, 2000.

[10] Mouhamad, R. S., Ghanem, I.; AlOrfi, M. Ibrahim, K.; Ali, N. \& Al-Daoude, A.. Phytoremediation of Trichloroethylene and Dichlorodiphenyltrichloroethane - Polluted Water Using Transgenic Sesbania Grandiflora and Arabidopsis Thaliana Plants Harboring Rabbit Cytochrome P450 2E1. Int. J. Phytorem, 14, 656-668, 2012 a.

[11] Mohammed, R. S., Ibrahim, K. M., Ali, N. A., AL-Daoude, A. Employment of plant biotechnologies with P4502E1 gene for treatment radionuclide pollution. Journal of Education and Science, Basic Sciences, University of Mousul, 25, 398-410, 2012b.

[12] Travis, E. R.; Hannink, N. K.; Van der Gast, C. J.; Thompson, I. P.; Rosser, S. J. and Bruce, N. C. Impact of transgenic tobacco on trinitrotoluene (TNT) contaminated soil community. Environ. Sci.and Techn., 41: 5854-5861, 2007.

[13] Rivera, R; Medina V. F.; Larson S. L. and McCutcheon, S. C. Phytotreatment of TNTcontaminated groundwater. J. of Soil Contamination, 7: 511-529, 1998.

[14] Parameswaran, A.; Leitenmaier, B.; Yang, M.; Kroneck, P. M.; Welte, W.; Lutz, G.; Papoyan, A.; Kochian, L. V. and Kupper, H. A native Zn/Cd pumping P (1B) ATPase from natural overexpression in a hyperaccumulator plant. Bioch. and Biophysical Research Communications, 363: 51-56, 2007.

[15] Bizily, S. P.; Rugh, C. L. and Meagher, R. B. Phytodetoxification of hazardous organomercurials by genetically engineered plants. Nature Biotech., 18: 213-217, 2000.

[16] Pilon, M.; Owen, J. D.; Garifullina, G. F.; Kurihara, T.; Mihara, H.; Esaki, N. and Pilon-Smits. E. H. Enhanced selenium tolerance and accumulation in transgenic Arabidopsis expressing a mouse selenocysteine lyase. Plant Physiology, 131: 1250-1257, 2003.

[17] Liang, Z.Y.; Pilon-Smits, E. A.; Jouanin, L. and Terry, N. Overexpression of glutathione synthetase in Indian mustard enhances cadmium accumulation and tolerance. Plant Physiology, 119: 73-80, 1999.

[18] Zhu, Y. L.; Pilon-Smits, E. A; Tarun, A. S.; Weber, S. U.; Jouanin, L. and Terry, N. Cadmium tolerance and accumulation in Indian mustard is enhanced by overexpressing gamma-glutamylcysteine synthetase. Plant Physiol., 121: 1169-1178, 2002.

[19] Banuelos, G.; Terry, N.; LeDuc, D. L.; Pilon-Smits, E. A. and Mackey, B. Field trial of transgenic Indian mustard plants shows enhanced phytoremediation of selenium-contaminated sediment. Environ. Sci. and Techn., 39: 1771-1777, 2005.

[20] Umeno, M., McBride, O. W., Yang, C. S., Gelboin, H. V., Gonzalez, F. J. Human ethanol-inducible P450IIE1: complete gene sequence, promoter characterization, chromosome mapping, and cDNA-directed expression. Biochemistry 27: 9006-9013, 1988.

[21] Comai L, Moran P, Maslyar D. Nove1 and useful properties of a chimeric plant promoter combining $35 \mathrm{~s}$ and MAS elements. Plant Mo1 Bioll5 373-381, 1990.

[22] McBride, O. W., Umeno, M., Gelboin, H. V., Gonzalez, F. J. A TaqI polymorphism in the human P450IIE1 gene on chromosome 10 (CYP2E). Nucleic Acids Res. 15: 10071, 1987.

[22] Steven, B. J; Veech R. L, and Saeng. Cytochrome P450IIE1 is elevated in lymphocytes from poorly controlled insulin-dependent diabetics. J. Clin. Endocrinol. Metab., 71: 1036-1040, 2008.

[23] Cangelosi, G.A., Best E.A., Martinetti C. and Nester E.W. Genetic analysis of Agrobacterium tumefaciens. Methods in Enzymology 145:177-181, 1991.

[24] Page, A.L.; Miller, R.H. and Kenney, D.R. Method of Soil Analysis, 2nd (ed) Agron. 9, Publisher, Madiason, Wisconsin, 1982.

[25] Bechtold, N., Elis, J. and Pelletetier, G. In planta Agrobacterium mediated gene transfer by infiltration of adult Arabidopsis thaliana. Acad. Sci., 316: 1194-1199, 1993.

[26] Selamat, S. N.; Abdullah, S. R.; Idris M. Phytoremediation of lead $(\mathrm{Pb})$ and arsenic (As) by Melastoma malabathricum L. from 
contaminated soil in separate exposure. Int

J. Phytorem., 16: 694-703, 2014.

[27] Divya, B.; Deepak Kumar, M. PlantMicrobe interaction with enhanced bioremediation. Jianwei, H.; Jianjun, W.; Berti, and Cunningham, U. Phytoremediation of lead-contaminated soils: role of synthetic chelates in lead phytoextraction. Environ. Sci. Techno., 31: 800-805, 1997.

[28] Meers, E.; van Slycken, S.; Adriaensen, K.; Ruttens, A.; Vangronsveld, J.; Du Laing, G.; Witters, N.; Thewys, T.; Tack, F.M. The use of bio-energy crops (Zea mays) for "phytoattenuation" of heavy metals on moderately contaminated soils: A field experiment. Chemosphere, 78, 35-41, 2010.

[29] Ruttens, A.; Boulet, J.; Weyens, N.; Smeets, K.; Adriaensen, K.; Meers, E.; van Slycken, S.; Tack, F.; Meiresonne, L.; Thewys, T.; et al. Short rotation coppice culture of willows and poplars as energy crops on metal contaminated agricultural soils. Int. J. Phytorem., 13, 194-207, 2011.

[30] Mouhamad, R. S., Ibrahim, K.; Ali, N.Ghanem, I.; \& Al-Daoude, A. Determination of heavy metal uptake in transgenic plants harbouring the rabbit CYP450 2E1 using X-ray fluorescence analysis. international Journal of Environmental Studies. 71, Issue 3, 2014a.

يتم التخلص من الملوثات بتطايرها من النبات بعد

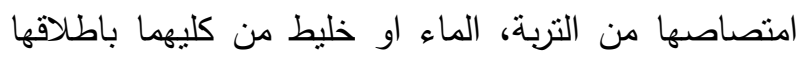
الى الغلاف الجوي غالبا عن طريق الثغور • تتاسب تلك الالية

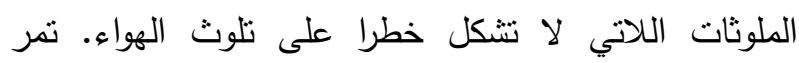
الملوثات الى اوراق النبات بعد امتصاصها من الجذور لتتطلق الى الهواء عبر الثغور حيث يحصل التبادل الغازي.

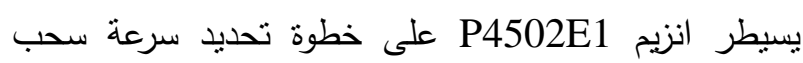
العديد من الملوثات البيئية بعد عمليات الايض الحيوي. بينت

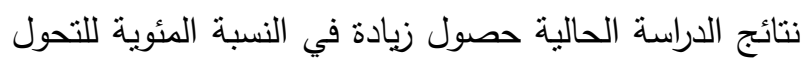
الوراثي لنبات الاربيدوبسيس Arabidopsis thaliana عند Agrobacterium استعمال محاليل مخففة من عالق بكتريا لإنيات tumefaciens التخلص من الملوثات التي شملت الصوديوم (Na)؛ المغنسيوم (Mg)، البوتاسيوم (K)، الكالسيوم (Ca)، المنغيز

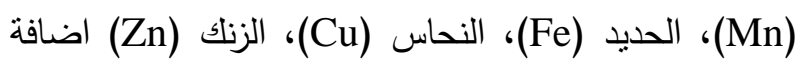

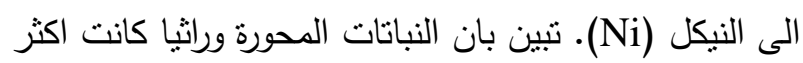

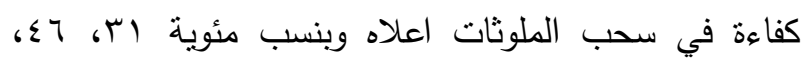
צ بالنباتات غير المحورة.

الكلمات المفتاحية: المعادن الثقيلة، التحوير الوراثي، .Agrobacterium tumefaciens

[31] Mouhamad, R. S., Ibrahim, K.; Ali, N.Ghanem, I.; \& Al-Daoude, A. Expression of P4502E1 phytoremediation gene in Sesbania grandiflora and Arabidopsis thaliana. Iraqi Journal of Agriculture.19: 154-164, 2014b.

[32] Natalia, D.; Wang, C. and Zhang, D. Progress in map based cloning of $X a 22$, a new gene for bacterial leaf blight resistance in rice. Paper presented at plant and animal genome conference. 18-22, 2002.

[33] Ali, H.; Khan, E.; Sajad, M.A. Phytoremediation of heavy metalsConcepts and applications. Chemosphere, 91, 869-881, 2013. 